\title{
PROFILING DEAF AND HARD-OF-HEARING USERS OF SUBTITLES FOR THE DEAF AND HARD-OF-HEARING IN ITALY: A QUESTIONNAIRE-BASED STUDY
}

\author{
Agnese Morettini \\ University of Macerata (Italy) \\ agnese.morettini@gmail.com
}

\begin{abstract}
The aim of this article is to present the results of a questionnaire-based study carried out as part of the author's Master's Degree dissertation about Subtitles for the Deaf and Hard-of-hearing (SDH). In particular, the need to gather specific information regarding audience design will be highlighted in the paper, since this research field has long been neglected in Italy.

The questions were aimed at shedding light on the needs, cultural environment and world-view of Italian SDH users, by eliciting personal data as well as subtitlerelated information. Moreover, the 232 respondents were asked to suggest improvements to SDH services in Italy.

Although these first results cannot allow definite conclusions because of the limited number of respondents to the survey, they might prove to be helpful for professional translators and subtitlers to better know their intended recipients.
\end{abstract}

\section{Resumen}

El objetivo del presente trabajo es dar a conocer los resultados de una investigación sobre subtítulos para sordos ( $\mathrm{SpS}$ ) llevada a cabo por la autora en el ámbito de su tesis de máster. En particular, se hace hincapié en la necesidad de disponer de la debida información acerca de las personas con discapacidad auditiva, un tema bastante descuidado en Italia hasta ahora.

Para ello ha sido elaborado un cuestionario que arroja luz sobre las necesidades, el entorno cultural y la visión del mundo de los usuarios de SpS en Italia. Asimismo 
los 232 entrevistados pudieron dar sugerencias sobre cómo mejorar los servicios italianos de SpS.

Aunque no se puedan sacar conclusiones generales de estos primeros resultados, dado el número limitado de encuestados, éstas podrán ser utiles para los traductores y subtituladores, puesto que muy raramente poseen información sobre el perfil de los usuarios de SpS.

Keywords: Audience design. Questionnaire-based study. SDH. Audience needs. Deaf and Hard-of-hearing users.

Palabras clave: Perfil de usuarios. Investigación mediante cuestionario. Subtitulado para sordos (SPS). Necesidades de la audiencia. Usuarios sordos.

Manuscript received on June 29, 2011; Definitely accepted on November 15, 2011. 


\section{Introduction}

In recent years, Accessibility and Disability Studies have gained wide recognition in the field of Audiovisual Translation. Emphasis has been placed above all on Subtitling for the Deaf and Hard-of-hearing (SDH) and Audio Description (AD) for the blind and visually impaired. However, Italy seems to be quite backward in terms of academic research in this field.

In Italy, SDH has been used since 1986, when Alfred Hitchcock's Rear Window was the first feature film to be aired with teletext subtitles on the public TV channel RAI (Liso et al. 2002: 185). From that year on, TV stations and DVD producers have been providing SDH on a regular basis. And yet, only lately has the Italian academic community begun to show interest in the study of accessible subtitling. As a result, there are still few Italian studies that focus on the analysis of SDH from an audiovisual perspective. In particular, little is known about the Italian deaf and hard-of-hearing audience: this fact suggests the need for more in-depth investigations into the field of audience design.

\subsection{Rationale of present study}

Western societies heavily rely on audiovisual media as means to disseminate information. When SDH is needed for people who suffer from hearing impairment to be successfully integrated into the information society, a number of operational criteria come into play:

- Semiotics of subtitling: the interrelation between dialogue, image, sound and subtitles, and the influence of filmic conventions on SDH (Ivarsson 1992; De Linde \& Kay 1999; Chaume 2004; Neves 2005; Díaz Cintas \& Remael 2007; Sokoli 2009).

- Adaptation of subtitles: the much debated question of the appropriated level of adaptation as opposed to requests for more verbatim subtitles (Jensema 1998; De Linde \& Kay 1999; Liso et al. 2002; Neves 2005; Ofcom 2005; Schilperoord et al. 2005; Di Silvio 2006).

- Spatial restrictions: the maximum number of lines available (usually two), the position of subtitles on screen, the justification of the 
subtitles and the maximum number of allowed characters per line (Neves 2005; Díaz Cintas \& Remael 2007).

- Temporal restrictions: the sound-subtitle synchronisation (leading and lagging) and the image-subtitle synchronisation (filmic conventions) (Ivarsson 1992; De Linde \& Kay 1999; Liso et al. 2002; Neves 2005).

- Conveyance of verbal information: emphasis, tone of voice, accents, dialects, foreign language and humour (De Linde \& Kay 1999).

- Conveyance of non-verbal information: the position, description and identification of speakers; sound effects; music and songs; silences (De Linde \& Kay 1999; Neves 2005; Tercedor Sánchez et al. 2007; Neves 2009).

- Presentation of the text and legibility of the text on screen: the choice of the font to be used, font colours, type and colours of subtitle background (Ivarsson 1992; Ofcom 2005; Clark 2006a, 2007a, 2007b; Díaz Cintas \& Remael 2007).

All of these criteria are influenced by one very basic but often overlooked variable: the actual audience, made up of deaf and hard-of-hearing viewers.

When giving prominence to the point of view of the deaf and hard-ofhearing viewers, two questions naturally arise:

1) Are people who prepare SDH aware of who their intended recipients are?

2) Do they know what their needs, preferences, expectations and requests are, so as to deliver a high-quality subtitled product that actually serves the purposes for which SDH is created in the first place?

At the moment, no Italian institution provides structured training programmes in media accessibility other than single courses in university degrees, summer schools or postgraduate masters programmes. Therefore, in most cases, those who are asked to produce SDH generally acquire the necessary skills through first-hand working experience. Translators and subtitlers working in this field are usually professional translators who, being already specialised in interlingual subtitling, are presumed to be able to cope with the peculiar issues that characterise SDH. But, as the very term suggests, subtitling for the deaf and hard-of-hearing has to cater for the special needs of a well-defined group of addressees. 
When translators and subtitlers are called upon to translate an audiovisual text into a target language, they are usually aware of the audience they are addressing because they share (or at least they should share) the same target language, culture and world-view of their intended recipients. Instead, when translators and subtitlers are asked to produce subtitles for a hearing impaired audience, they do not share the same cultural environment, set of knowledge and world-view of their intended recipients, as they must be hearing people in order to be able to do the job.

Because of the current lack of academic and professional training courses offered by Italian institutions, as well as solid scientific studies regarding the composition of the Italian deaf and hard-of-hearing audience, ${ }^{1}$ translators and subtitlers may often have no other choice than to try and guess the needs, preferences, expectations and requests of this peculiar kind of audience.

\subsection{Aim of the present research}

The empirical study herewith reported was designed so as to investigate on the composition of a group of Italian SDH users, in an attempt to identify their peculiar needs, expectations, preferences and requests.

The information thus collected might be used as a guide by professional translators and subtitlers in the definition of adequate SDH operational criteria to be applied when creating or adapting subtitles for the hearing impaired.

\subsection{Chosen method of study and study design}

The data regarding a group of Italian SDH users were collected upon questionnaire completion. ${ }^{2}$

In support of the main goal of this research, the present study set out to give a precise answer to the following questions:

1. Only another article seems to have been published on the topic of Deaf and Hard-ofhearing audience analysis in Italy, that is, a research study conducted by the ENS (2002), the Italian National Association of Deaf people. However, this survey study focused only on assessing the levels of user satisfaction in television subtitling.

2. The questionnaire here presented has been developed and administered as part of the author's research for her Master's Degree dissertation, entitled Subtitling for the Deaf and Hard-of-hearing in Italy: How and why. An example of production process and subtitling best practices for cinema and DVD industries, defended on March, 30 2011 and tutored by professor Elena Di Giovanni (University of Macerata). The results of this questionnaire were also presented by the author at the international conference on Screen Translation, ScreenIT2010, organised by the Advanced School of Modern Languages for Interpreters and Translators (University of Bologna at Forlì) in October 2010. 
1) What are the personal characteristics that shape the needs of Italian SDH users in terms of subtitling?

2) How do Italian SDH users perceive and judge SDH in its current form in Italy?

3) What other measures would Italian SDH users like to see being taken in the field of media accessibility, in particular, regarding subtitling?

The questionnaire was designed and structured so as to mirror this sequence of questions.

\section{Method}

\subsection{Participants}

In order to answer the questions posited in section 1.3, the survey was submitted to a wide-ranging sample of deaf and hard-of-hearing people. The eligibility criteria for inclusion in the study were: being an Italian citizen, and suffering from some kind of hearing impairment.

No hearing people took part in this survey. This choice was intentional, given the specific aim of the research. The questionnaire was to be taken individually and was anonymous. A total of 234 people took part in this study. Only two of them did not complete all the questions that were asked in the questionnaire form.

\subsection{Preparatory work: procedure and structure}

The survey had to be completed online by clicking on a URL address that linked to the free-of-charge website platform used to create the questionnaire, called eSurveysPro.com.

The questionnaire was available online from April $26^{\text {th }}$ to May $26^{\text {th }} 2010$. The questions, twenty in all, were phrased and structured as: single choice questions; multiple choice questions; matrix choice questions; and free text box questions.

The blank survey was posted on an online forum called "Sordità Online" (http://www.sorditaonline.it/forum3/index.php). This is a meeting place on the Web, where people with different degrees of hearing impairment join together regularly to discuss issues regarding not only $\mathrm{SDH}$, but also problems linked to deafness in general. Social networks also played a big role in attracting more people to complete the questionnaire, as this was also posted on various groups on Facebook that deal with deafness and SDH. A list of these groups follows: 
- FIADDA Umbria Onlus

- Tutti i sordi italiani in gruppo: iscrivetevi e condividete se siete sordi!

- Sordi italiani unitevi! Per la riappacificazione tra ENS e FIADDA

- Vlog Sordi

- Sottotitoli in tutte le TV italiane e al cinema

- Deafhood - Il popolo dei sordi

- Sottotitolazione e audiodescrizione televisiva cinematografica e teatrale

The choice to promote the questionnaire on new channels of communication was rooted in the very intention of the survey: that of gathering Italian deaf and hard-of-hearing people from different backgrounds, lifestyles, interests and ages, so that this research could be as wide-ranging as possible in the representation of a portion of Italian SDH users.

In order to answer the three specific questions that fulfil the aim of this research (see Paragraph 1.3.), the survey was structured and divided into three sections:

1) Demographic profile and personal data: questions 1-12;

2) Subtitle-related questions: questions 13-19;

3) Free text space for suggestions: question 20.

Finally, the relevant data gathered through the questionnaire were examined using the analysis tool of eSurveysPro.com. When cross-analyses among questions or groups of questions were needed, the information was processed using Microsoft Excel 2007.

\section{Results}

The results of the questionnaire are tabulated in Table 1, Table 2 and Table 3 below. They are presented in three paragraphs, each one corresponding to the sections in which the questionnaire was organised: 1) Personal characteristics; 2) Subtitle-related questions; 3) Suggestions and comments. 


\subsection{Survey participants' personal characteristics}

\begin{tabular}{|c|c|c|}
\hline & Characteristics & Respondents (\%) \\
\hline $\begin{array}{l}\text { Single choice question } \\
\text { Silla }\end{array}$ & $\begin{array}{l}\text { Sex: } \\
\text { a. Male } \\
\text { b. Female } \\
\end{array}$ & $\begin{array}{l}129(55.60) \\
103(44.40)\end{array}$ \\
\hline $\begin{array}{l}2 \\
\text { Single choice question }\end{array}$ & $\begin{array}{ll}\text { Age: } \\
\text { a. } 0-14 \\
\text { b. } 15-24 \\
\text { c. } 25-40 \\
\text { d. } 41-59 \\
\text { e. } 60-74 \\
\text { f. } 75+\end{array}$ & $\begin{array}{c}1(0) \\
19(8) \\
97(41) \\
105(45) \\
10(4) \\
0(0)\end{array}$ \\
\hline $\begin{array}{l}3 \\
\text { Single choice question }\end{array}$ & $\begin{array}{l}\text { Education level: } \\
\text { a. First school degree } \\
\text { b. Second school degree } \\
\text { c. High school degree } \\
\text { d. University degree } \\
\text { e. Doctoral degree } \\
\end{array}$ & $\begin{array}{c}4(1.72) \\
69(29.74) \\
129(55.60) \\
30(12.93) \\
0(0) \\
\end{array}$ \\
\hline $\begin{array}{l}4 \\
\text { Single choice question }\end{array}$ & $\begin{array}{l}\text { Education in schools for } \\
\text { deaf and hard-of-hearing } \\
\text { children: } \\
\text { a. Yes } \\
\text { b. No } \\
\end{array}$ & $\begin{array}{l}135(58.19) \\
97(41.81) \\
\end{array}$ \\
\hline $\begin{array}{l}5 \\
\text { Single choice question }\end{array}$ & $\begin{array}{l}\text { Current occupation: } \\
\text { a. Study } \\
\text { b. Unemployed or cannot } \\
\quad \text { work } \\
\text { c. Retired } \\
\text { d. Other (work) } \\
\end{array}$ & $\begin{array}{c}34(14.66) \\
23(9.91) \\
22(9.48) \\
153(65.95)\end{array}$ \\
\hline $\begin{array}{l}6 \\
\text { Single choice question }\end{array}$ & $\begin{array}{l}\text { Level of hearing loss: } \\
\text { a. Mild }(20-40 \mathrm{~dB}) \\
\text { b. Moderate }(41-70 \mathrm{~dB}) \\
\text { c. Severe }(71-90 \mathrm{~dB}) \\
\text { d. Profound }(91-120 \mathrm{~dB}) \\
\text { e. Cophosis }(121+\mathrm{db}) \\
\end{array}$ & $\begin{array}{c}5(2.16) \\
19(8.19) \\
80(34.48) \\
110(47.41) \\
18(7.76)\end{array}$ \\
\hline $\begin{array}{l}7 \\
\text { Single choice question }\end{array}$ & $\begin{array}{l}\text { Age of onset of deafness/ } \\
\text { hearing impairment: } \\
\text { a. From birth } \\
\text { b. } 0-18 \text { months } \\
\text { c. } 18 \text { months }-3 \text { years } \\
\text { d. } 4-19 \text { years } \\
\text { e. 20-34 years } \\
\text { f. 35-54 years } \\
\text { g. 55-74 years } \\
\text { h. } 75+\text { years }\end{array}$ & $\begin{array}{c}129(55.60) \\
44(18.97) \\
38(16.38) \\
16(6.90) \\
2(0.86) \\
2(0.86) \\
0(0) \\
1(0.43)\end{array}$ \\
\hline
\end{tabular}




\begin{tabular}{|c|c|c|}
\hline $\begin{array}{l}8 \\
\text { Single choice question }\end{array}$ & $\begin{array}{l}\text { Use of hearing aids: } \\
\text { a. Hearing aids } \\
\text { b. Cochlear implant } \\
\text { c. Other }\end{array}$ & $\begin{array}{c}149(64.22) \\
9(3.88) \\
74(31.90)\end{array}$ \\
\hline $\begin{array}{l}9 \\
\text { Multiple choice question }\end{array}$ & $\begin{array}{l}\text { Method of communication: } \\
\text { a. Italian sign language } \\
\quad \text { (LIS) } \\
\text { b. Oral language } \\
\text { c. Both (LIS + oral } \\
\text { language) } \\
\text { d. Lip-reading } \\
\text { e. Other }\end{array}$ & $\begin{array}{c}59(20.77) \\
57(20.07) \\
128(45.07) \\
\\
32(11.27) \\
8(2.82)\end{array}$ \\
\hline $\begin{array}{l}10 \\
\text { Multiple choice question }\end{array}$ & $\begin{array}{l}\text { Eyesight problems: } \\
\text { a. No } \\
\text { b. Myopia } \\
\text { c. Presbyopia } \\
\text { d. Astigmatism }\end{array}$ & $\begin{array}{l}141(57.55) \\
61(24.90) \\
11(4.49) \\
32(13.06)\end{array}$ \\
\hline $\begin{array}{l}11 \\
\text { Single choice question }\end{array}$ & $\begin{array}{l}\text { Reading deficiencies (e.g. } \\
\text { dyslexia): } \\
\text { a. Yes } \\
\text { b. No } \\
\end{array}$ & $\begin{array}{r}18(7.76) \\
214(92.24) \\
\end{array}$ \\
\hline $\begin{array}{l}12 \\
\text { Single choice question }\end{array}$ & $\begin{array}{l}\text { Affiliation to Italian } \\
\text { associations for the Deaf } \\
\text { and Hard-of-Hearing: } \\
\text { a. No } \\
\text { b. ENS } \\
\text { c. FIADDA } \\
\text { d. Other }\end{array}$ & $\begin{array}{c}38(16.38) \\
173(74.57) \\
12(5.17) \\
9(3.88)\end{array}$ \\
\hline
\end{tabular}

Table 1. Socio-demographic and physical characteristics of the group of Italian survey respondents

Out of 232 respondents who completed the questionnaire, 202 were aged 25 to 59. The sample of people who took the questionnaire shows that two poles, namely the age groups 0-24 and 60-75+ respectively, were not adequately represented. The low participation of people aged $60+$ can be attributed to the fact that the survey was posted on the Internet. New channels of communication, such as forums and social networks, have been used to disseminate the questionnaire, and the case could be that older Italian people are not quite accustomed to using them yet.

Regarding the educational level, the survey shows that the majority of respondents $(55.60 \%)$ obtained a high school diploma, while 69 out of 232 respondents (29.74\%) held a middle school diploma. This means that $85.34 \%$ of the sample would eventually have adequate to high levels of literacy. What is interesting, though, is the low number of respondents that completed a university programme. Actually, only 12 out of 232 respondents held a university 
degree while none of them succeeded in earning a doctorate degree. These data mirror a very common situation in Italy, where disabled people in general, and hearing impaired people in particular, tend to encounter many difficulties when deciding to graduate or enter a doctorate programme.

The data regarding the professional background of the respondents testifies to the integration of deaf and hard-of-hearing people in the Italian working sector. As a matter of fact, the majority of the sample (65.95\%) turned out to be employed.

As far as the level of hearing loss is concerned, the majority of respondents (81.89\%) suffer from severe or profound deafness, while $7.76 \%$ is completely deaf. These results may be integrated into the answers given to Question 7, which regards the age of onset of the hearing impairment.

The data gathered in the present study reveal that more than half of the respondents $(55.60 \%$ ) are born deaf, while $18.97 \%$ of the respondents became deaf aged 0 to 18 months and $16.38 \%$ of the respondents became deaf aged 18 months to 3 years. The results obtained by cross-analysing the answers given to Questions 6 and 7 (see Chart 1 below) show that the majority of respondents who suffer from severe, profound or total deafness were born deaf or started to suffer from deafness before having turned 3. As Adams \& Rohring (2004: 17) state,

the age of onset of hearing loss is important as a base for acquiring and using spoken language. Individuals who experience a hearing loss before they acquire speech and spoken language, typically before the age of 3 , are considered to have prelingual hearing loss.

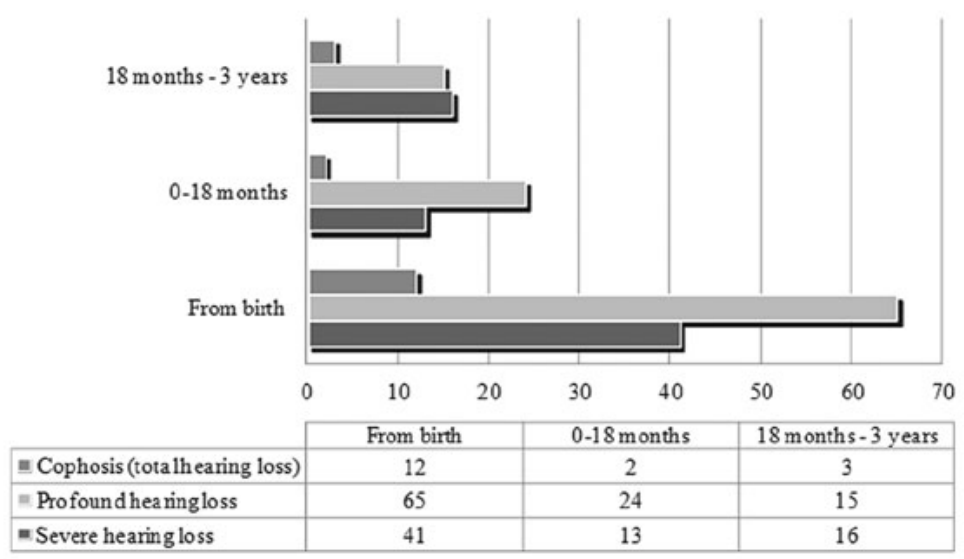

Chart 1 - Relationship between level of deafness and age of onset of deafness (y-axis: age of onset; $\mathrm{x}$-axis: number of respondents) 
As shown in Chart 1 above, respondents to the questionnaire were mostly prelingual deaf people, who are most likely to use sign language as their first language. Actually, according to Adams \& Rohring (2004: 17), "individuals with prelingual hearing loss [...] are often delayed in [...] language achievement because they primarily use visual means to communicate rather than oral or aural means."

In this context, the use of hearing aids (Question 8) may help deaf, but above all, hard-of-hearing people to use the oral language as their first language, especially if deafness shows itself during the first three years of a child's life and if it is of a mild or moderate entity. The results of the present survey indicate that a vast majority of respondents (64.22\%) use hearing aids, while only a small portion of them (3.88\%) opted for cochlear implants. This last option is obviously a bigger and much more invasive choice, and this might be the reason why so few respondents have chosen to go through it. The choice of raising a deaf or hard-of-hearing child according to one approach or the other, signing as opposed to oralist respectively, has consequences for cognitive and language development.

Notwithstanding what has been said above, many respondents do not use only one way of communication. The data that result from cross-analysing the answers to Questions 6, 7 and 9 demonstrate that a great majority of deaf respondents (those who suffer from severe, profound or total deafness) are also able to communicate orally, even though they know and use sign language too. In particular, here are the data concerning those who can communicate orally, as well as by using a combination of sign language, oral language and/ or lip reading:

- 34 people born deaf who suffer from severe hearing loss out of 41 ;

- 54 people born deaf who suffer from profound hearing loss out of 65 ;

- 9 people born deaf who suffer from total deafness out of 12;

- 8 people who grew deaf aged 0-18 months and suffer from severe hearing loss out of 13;

- 15 people who grew deaf aged 0-18 months and suffer from profound hearing loss out of 24;

- 1 person who grew deaf aged 0-18 months and suffers from total hearing loss out of 2;

- 14 people who grew deaf aged 18-36 months and suffer from severe hearing loss out of 16 ; 
- 15 people who grew deaf aged 18-36 months and suffer from profound hearing loss out of 15 ;

- 1 person who grew deaf aged 18-36 months and suffers from total hearing loss out of 2 .

These results demonstrate that, even if the majority of the sample is composed of people who suffer from severe, profound and total deafness from birth, the great majority of respondents are able to communicate using both sign language and oral language. This result may also have been achieved thanks to the widespread use of hearing aids by the respondents.

The following two questions (10 and 11) were designed so as to examine the possible consequences of eyesight problems and reading deficiencies on the reception of subtitles by deaf and hard-of-hearing viewers. As far as eyesight problems are concerned, these might negatively affect the legibility of the subtitles presented on screen. Although the majority of respondents do not suffer from any eyesight problems $(57.55 \%)$, a relatively noticeable percentage of them (37.96\%) does suffer from myopia or astigmatism (37.96\%). These types of eyesight problems might jeopardise the optimal reception of subtitles, especially if deaf and hard-of-hearing viewers who suffer from myopia or astigmatism sit too far from the screen, be it at home or at the cinema.

Another possible obstacle to the correct reception of the text presented on screen is when deaf or hard-of-hearing viewers suffer from reading deficiencies, like dyslexia. The data gathered from the questionnaire show that only 18 out of 232 respondents (7.76\%) do suffer from any reading deficiencies: even if this is a small percentage, it accounts for an existing problem.

The last question of this section inquired about respondents' affiliation to Italian associations for Deaf and Hard-of-hearing people. The majority of respondents (173 out of 232) are affiliated with the ENS (the Italian National Association of Deaf people), which is a body that represents and safeguards the rights and interests of Italian Deaf and Hard-of-hearing people by law. Second comes the FIADDA (Association of the Italian Families for the Defence of Hearing Impaired People's Rights), with only 12 associated respondents out of 232 .

\subsection{Survey participants' response to subtitle-related questions}

The second section of the questionnaire addressed subtitle-related issues. The questions (see Table 2) were designed so as to gather information about Italian users' subtitling preferences. 


\begin{tabular}{|c|c|c|}
\hline & Subtitle-related questions & Respondents (\%) \\
\hline $\begin{array}{l}13 \\
\text { Multiple choice question }\end{array}$ & $\begin{array}{l}\text { Which of these media do } \\
\text { you mostly use with SDH? } \\
\text { a. Analogue television } \\
\text { b. Digital television } \\
\text { c. Satellite television } \\
\text { d. DVD/Blu-Ray } \\
\text { e. Cinema } \\
\text { f. Other }\end{array}$ & $\begin{array}{c}120(24.59) \\
139(28.48) \\
65(13.32) \\
114(23.36) \\
41(8.40) \\
9(1.84)\end{array}$ \\
\hline $\begin{array}{l}14 \\
\text { Single choice question }\end{array}$ & $\begin{array}{l}\text { How long have you been } \\
\text { using SDH? } \\
\text { a. Less than } 1 \text { year } \\
\text { b. } 1-5 \text { years } \\
\text { c. 6-10 years } \\
\text { d. 11-19 years } \\
\text { e. More than } 20 \text { years } \\
\end{array}$ & $\begin{array}{c}3(1.29) \\
21(9.05) \\
39(16.81) \\
72(31.03) \\
97(41.81) \\
\end{array}$ \\
\hline $\begin{array}{l}15 \\
\text { Matrix single choice } \\
\text { question }\end{array}$ & $\begin{array}{l}\text { According to you, what is } \\
\text { the quality of SDH today } \\
\text { in Italy? } \\
\text { On television (pre-recorded } \\
\text { subtitles) } \\
\text { a. Insufficient } \\
\text { b. Sufficient } \\
\text { c. Acceptable } \\
\text { d. Good } \\
\text { e. Very good } \\
\text { On television (live subtitles) } \\
\text { a. Insufficient } \\
\text { b. Sufficient } \\
\text { c. Acceptable } \\
\text { d. Good } \\
\text { e. Very good } \\
\text { On DVDs } \\
\text { a. Insufficient } \\
\text { b. Sufficient } \\
\text { c. Acceptable } \\
\text { d. Good } \\
\text { e. Very good }\end{array}$ & $\begin{array}{c}43(18) \\
78(33) \\
64(27) \\
37(15) \\
10(4) \\
\\
98(42) \\
72(31) \\
38(16) \\
19(8) \\
5(2) \\
\\
8(3) \\
28(12) \\
42(18) \\
75(32) \\
79(34)\end{array}$ \\
\hline $\begin{array}{l}16 \\
\text { Single choice question }\end{array}$ & $\begin{array}{l}\text { How many hours do you } \\
\text { watch TV daily? } \\
\text { a. I do not watch TV } \\
\text { b. Less than } 1 \text { hour } \\
\text { c. } 1-2 \text { hours } \\
\text { d. } 2-3 \text { hours } \\
\text { e. 3-4 hours } \\
\text { f. More than } 4 \text { hours }\end{array}$ & $\begin{array}{c}1(0.43) \\
24(10.34) \\
78(33.62) \\
73(31.47) \\
32(13.79) \\
24(10.34)\end{array}$ \\
\hline
\end{tabular}




\begin{tabular}{|c|c|c|}
\hline $\begin{array}{l}17 \\
\text { Multiple choice question }\end{array}$ & $\begin{array}{l}\text { What kind of subtitled } \\
\text { TV programmes do you } \\
\text { usually watch? } \\
\text { a. Films and TV series } \\
\text { b. News } \\
\text { c. Talk-shows and } \\
\text { entertainment } \\
\text { programmes } \\
\text { d. Documentaries } \\
\text { e. Sport } \\
\text { f. Other }\end{array}$ & $\begin{array}{c}216(31.30) \\
194(28.12) \\
68(9.86) \\
\\
130(18.84) \\
65(9.42) \\
17(2.46)\end{array}$ \\
\hline $\begin{array}{l}18 \\
\text { Single choice question }\end{array}$ & $\begin{array}{l}\text { According to you, which } \\
\text { TV channels offer better } \\
\text { subtitles in terms of } \\
\text { quality? } \\
\text { a. Rai (Uno, Due and Tre) } \\
\text { b. Mediaset (Rete 4, Canale } \\
\quad 5 \text {, Italia Uno) } \\
\text { c. La7 } \\
\text { d. Sky } \\
\text { e. Other }\end{array}$ & $\begin{array}{c}117(50.43) \\
44(18.97) \\
\\
2(0.86) \\
55(23.71) \\
14(6.03)\end{array}$ \\
\hline $\begin{array}{l}19 \\
\text { Multiple choice question }\end{array}$ & $\begin{array}{l}\text { According to which criteria } \\
\text { do you judge the quality of } \\
\text { TV SDH? } \\
\text { a. Quantity of offered } \\
\text { subtitles } \\
\text { b. Type of language used } \\
\text { c. Synchronicity with } \\
\text { spoken dialogue } \\
\text { d. Speed of subtitles } \\
\text { e. Adaptation of subtitles } \\
\text { f. Legibility of subtitles on } \\
\text { screen } \\
\text { g. Other }\end{array}$ & $\begin{array}{c}100(19.80) \\
69(13.66) \\
77(15.25) \\
91(18.02) \\
62(12.28) \\
98(19.41) \\
8(1.58)\end{array}$ \\
\hline
\end{tabular}

Table 2 - Survey participants' response to subtitle-related questions

The first question of the second section suggests that subtitles are mostly used by Italian deaf and hard-of-hearing people on TV and DVDs, while only a small percentage of respondents (8.40\%) regularly enjoy subtitled films at the cinema. These data reflect a national trend, according to which only a few cinemas, usually located in the big cities, offer regular subtitled screenings (Pirelli 2005).

Question 14 regarded familiarity in using SDH: according to the data gathered through the survey, $72 \%$ of all respondents said they have been using subtitling for over 11 years. 
Question 15 was designed with the intention of investigating how the respondents judge the quality of SDH services as they are currently provided on Italian TV channels and on the DVDs released in Italy. As far as TV channels were concerned, a distinction between pre-recorded and live subtitling was made, in order to account for all types of subtitles that are currently available on Italian TV channels. The answers to this question show that the respondents deem DVD subtitles as good (32\%) and very good (34\%). To the contrary, TV subtitles did not meet with as much success: only 47 out of 232 respondents thought that pre-recorded TV subtitles are good to very good. The majority of them (33\%), instead, think that these are just of a sufficient quality. The worst results, though, were scored by live subtitles on TV: the great majority of respondents (42\%) deemed them as of insufficient quality, while only a mere $10 \%$ of them judged live subtitles on TV as good or very good. This might be due to the fact that RAI, the Italian state-owned public service broadcaster, began experimenting with live subtitling only in 2008: according to RAI (2011: 6), in 2010, 46\% of all Italian subtitles were created through stenography while $14 \%$ through voice recognition. This new service has since been used to subtitle mainly the news and talk shows and is still in its experimental phase. As far as the other private broadcasting companies are concerned (Mediaset Rete 4, Canale 5 and Italial, and La7), no officially published data have been found regarding their subtitling policies to the benefit of their hearing impaired viewers.

The third question of this section regarded how many hours of TV the respondents usually watch daily. The data gathered from the analysis of this question show that the majority of respondents (65.09\%) usually watch 1 to 3 hours of TV on a daily basis.

The following point in the survey, Question 17, dealt with the types of subtitled TV programmes usually watched by the respondents. The results indicate that the majority of respondents $(31.30 \%)$ prefer watching films and TV series, while live programmes such as talk-shows, entertainment programmes and sport programmes scored lower percentages (9.86\% and 9.82\% respectively). The bad results reported by live programmes probably originate from the fact that they are usually subtitled live.

The last two questions of this section were designed to scrutinise how quality is perceived as far as TV subtitling is concerned. Question 18, in particular, asked respondents which TV channels they thought currently provide better quality subtitling. The great majority of respondents (117 out of 232) chose RAI. 
Question 19 asked respondents to indicate which criteria they use in order to assess the quality of a subtitled programme: quantity was the most chosen answer (19.80\%), followed by the legibility of subtitles on screen (19.41\%) and the speed of subtitles (18.02\%).

\subsection{Survey participants' suggestions}

The third and last section of the questionnaire (Question 20) was a free-text space question where respondents could express their personal preferences, expectations, requests and suggestions regarding subtitling for the deaf and hard-of-hearing. Out of 232 respondents, 113 decided to take this question, thus adding a personal contribution to this study. The suggestions expressed by the respondents can be classified into four groups, which correspond to the most submitted proposals:

1) Request for $100 \%$ subtitling (commercial breaks included), 24 hours a day, 7 days a week, on all TV channels, especially on digital TV channels and on the public TV channels of RAI. Moreover, many respondents lamented the fact that they are obliged by law to pay a TV licence fee but that, unlike their hearing peers, they cannot enjoy all programmes as not all of them are subtitled;

2) Request for lower levels of adaptation, in favour of more verbatim subtitles;

3) Request for more subtitling at cinemas;

4) Request for TV broadcasters to pay more attention so as to avoid technical problems, such as the interruption of subtitles transmission in the middle of a programme or film, or after a commercial break.

Following are some of the answers that were given by the respondents to this last open question: 


\begin{tabular}{|c|c|}
\hline Respondents' answers to Question 20 & Translation into English \\
\hline \multicolumn{2}{|c|}{ Request for $100 \%$ subtitling } \\
\hline $\begin{array}{l}\text { Salve, A mio parere per ora sono contento a } \\
\text { metà, perchè in tv non fa vedere sottotitoli } \\
\text { in } 24 \text { su } 24 \text { ore, così sarebbe più giusto per } \\
\text { dare e capire al } 100 \% \text {, noi abbonati paghia- } \\
\text { mo al } 100 \% \text { quanto noi sordi abbiamo di- } \\
\text { ritto di vedere sottotitoli alla totalità. Saluti } \\
\text { da un sardo }\end{array}$ & $\begin{array}{l}\text { Hi, I'm only half happy, because TV pro- } \\
\text { grammes do not have subtitles } 24 / 7 \text {, this } \\
\text { would be only fair in order for us to be able } \\
\text { to understand } 100 \% \text {, we pay } 100 \% \text { and, be- } \\
\text { cause of this, we have the right to benefit } \\
\text { from total subtitling. Greetings from Sar- } \\
\text { dinia }\end{array}$ \\
\hline $\begin{array}{l}\text { l'offerta è molto limitata,fa eccezione rai3 } \\
\text { che però ha una sottotitolazione di scarsa } \\
\text { qualità come il resto. Manca una seria of- } \\
\text { ferta dedicata alle tematiche della cultura, } \\
\text { medicina, politica.. }\end{array}$ & $\begin{array}{l}\text { the offer is very limited, with the exception } \\
\text { of Rai3, but this is badly subtitled, as is the } \\
\text { case with all the other TV channels. The of- } \\
\text { fer is lacking, while it should cover the top- } \\
\text { ics of culture, medicine, politics... }\end{array}$ \\
\hline $\begin{array}{l}\text { Si dovrebbe aumentare l'offerta dei pro- } \\
\text { grammi sottotitolati in tutti i canali Rai e } \\
\text { Mediaset. E questo per quanto riguarda tut- } \\
\text { ti gli orari di programmazione, non soltan- } \\
\text { to per la serata. In più sarebbe bello che ci } \\
\text { fossero sottotitoli anche per i nuovi canali } \\
\text { digitali come Rai 4, Iris ecc... }\end{array}$ & $\begin{array}{l}\text { The offer of subtitled programmes should } \\
\text { be increased on all Rai and Mediaset TV } \\
\text { channels. And this should regard all show- } \\
\text { times, not only the evenings. Moreover, it } \\
\text { would be nice that the new digital TV chan- } \\
\text { nels be subtitled too (e.g. Rai 4, Iris, etc.) }\end{array}$ \\
\hline $\begin{array}{l}\text { Attualmente in Italia si passa dall'analogico } \\
\text { al digitale, ma i nuovi canali che si affaccia- } \\
\text { no al digitale sono privi di sottotitoli. Provo } \\
\text { molta rabbia per il fatto che almeno i film, } \\
\text { telefilm, documentari non siano sottotitolati } \\
\text { all'origine come il sonoro. Non comprendo } \\
\text { il fatto che un film che oggi è trasmesso su } \\
\text { un canale con sottotitoli tra qualche mese } \\
\text { mi venga riproposto in un altro canale ma } \\
\text { privo di sottotitoli. Mi auguro che si possa } \\
\text { trovare una soluzione a questo problema. } \\
\text { Se i sottotitoli fossero obbligati dalla legge a } \\
\text { essere applicati tutte le nuove produzioni, i } \\
\text { sottotitoli sarebbero indivisibili dal film. te- } \\
\text { lefilm ecc.. e quindi essendo applicati senza } \\
\text { ulteriori costi da tutti i media, la diffusione } \\
\text { dei sottotitoli avrebbe la giusta diffusione } \\
\text { che tutti i sordi desiderano. }\end{array}$ & $\begin{array}{l}\text { As of today, Italy is moving from analogue } \\
\text { to digital technology, but the new digital } \\
\text { TV channels do not have subtitles for the } \\
\text { hearing impaired. I am very angry, because } \\
\text { films, TV series or documentaries are not } \\
\text { subtitled from the very beginning as is the } \\
\text { case for dubbing. I really do not understand } \\
\text { why a film that is broadcast on analogue } \\
\text { TV today is not going to be subtitled when } \\
\text { is broadcast again on digital TV channels. } \\
\text { I hope that a solution to this problem will } \\
\text { be found soon. If all new productions were } \\
\text { obliged by law to provide subtitles for the } \\
\text { hearing impaired, subtitles would be insep- } \\
\text { arable from the film or TV series, etc.. and, } \\
\text { therefore, if no additional costs arose, the } \\
\text { diffusion of subtitles would be the one that } \\
\text { all deaf people wish. }\end{array}$ \\
\hline & $\begin{array}{l}\text { To increase SDH in every kind of pro- } \\
\text { gramme }\end{array}$ \\
\hline $\begin{array}{l}\text { voglio aumento i sottotitoli su } 24 / 24 \text { ore } \\
\text { tutti i programmi tv. }\end{array}$ & $\begin{array}{l}\text { I want an increase in subtitling } 24 / 7 \text { on all } \\
\text { TV programmes. }\end{array}$ \\
\hline $\begin{array}{l}\text { Mi piacerebbe vedere tutto SOTTOTITO- } \\
\text { LATO dico dappertutto almeno 90/100\% in } \\
\text { tutti i canali } 24 \mathrm{~h} \text { su } 24 \mathrm{~h} \text { e anche vorrei nel- } \\
\text { le pubblicità. Ricorda che in America sono } \\
\text { molto avanzati rispetto a noi e qui ancora in } \\
\text { Italia ancora molto indietro :--( }\end{array}$ & $\begin{array}{l}\text { I'd like to have all TV programmes subti- } \\
\text { tled, and I mean, everywhere, in at least } \\
90-100 \% \text { of the cases, } 24 / 7 \text { and also dur- } \\
\text { ing commercial breaks. In the US they have } \\
\text { made huge improvements when compared } \\
\text { to us, Italy is still backward :-( }\end{array}$ \\
\hline
\end{tabular}


I sottotitoli dovrebbero essere disponibili in qualsiasi programma, in qualsiasi spot, dovrebbero essere disponibili al momento dell'accensione della tv azionando ovviamente il tasto txt del telecomando. Noi sordi vogliamo questo, non che ci troviamo davanti un film bellissimo senza sottotitoli come accade di solito, che delusione.

Vorrei che ci fosse una legge nazionale che obbliga tutte le emittenti televisive (RAI, Mediaset e Sky) a sottotitolare il 100\% dei programmi TV come avviene negli USA e nel Regno Unito.
Subtitles should be available on every programme, commercial breaks included, right away when you turn on the TV, by pressing the Teletext button on the remote control. We, deaf people, want this, and do not want to have to see a film without subtitles, as usually happens. How disappointing!

I'd like that a national law be passed, compelling all broadcasters (RAI, Mediaset and Sky) to subtitle $100 \%$ of all TV programmes, as happens in the US and the United Kingdom. sinceramente non sono contenta, perché... 1 - i sottotitoli spesso è il riassunto del riassunto, inoltre i sottotitoli non correttamente ad esempio nel film uno dice: va bene (audio) ok (sottotitoli) non sono d'accordo... poi i sottotitoli: la frase è molto povera ed elementare. 2 - dovrebbe mettere sottotitoli 24 ore su 24 ore anche la pubblicità come l'audio... visto io pago puntuale il canone 3 - a voltei sottotitoli le parole sono errate o "immobili" in bocca al lupo.

Mi auguro che la sottotitolazione miglior soprattutto nelle dirette, i contenuti siano fedeli al pensiero di chi parla e intelligibil e che la velocità di scorrimento sia tale da permettere l'intera lettura Auguri per la tua tesi

Purtroppo i servizi di sottotitolazioni non sono gradevoli!!! Ho notato che spesso ciò che dicono gli attori, presentatori ecc...e sottotitoli non li scrivono e si ha meno partecipazione diretta con i film ecc... per me dovrebbero scrivere tutto anche se parlano i dialetto o parole complicati...vanno scritti cmq!!!e spesso sono pochi film sottotitolati e seguo per nulla i programmi televisivi perchè fin da piccola non offrivano i servizi. spero proprio che con il tempo migliori!!!
To be honest, I am not happy because... 1 - subtitles are often a summary of the summary, and they are not faithful to what is being said on screen, for example if one says: "it's all right" (in the soundtrack), you see "it's ok" in the subtitles, I do not agree with that. 2 - subtitles should be available $24 / 7$, even during commercial breaks, as it happens with the soundtrack, given that I always and timely pay the TV license fee 3 - sometimes the words in the subtitles are wrong or they "freeze", all the best.

I really wish that subtitling would get better, above all on live programmes, and that their content would be more faithful and intelligible and the subtitle presentation speed would allow sufficient time for reading.

Unfortunately, subtitling services are not enjoyable!!! I have noticed that what is being said by actors, TV presenters, etc... is not often written down in the subtitles and this lowers the involvement in the film, etc... in my opinion, they should write everything down, even if the characters speak with a dialect or if they use complex words... they should write them down all the same!!! And the offer of subtitled films is very limited and I do not watch TV programmes because subtitled programmes were not available when I was a little child... I really hope that they improve as the time goes by!!! 
la sottotitolazione, della tv, deve seguire Subtitling on TV has to follow closely what fedelmente alle parole dettate dall'interlo- is being said by the character without ever cutore senza mai sotituire o abbreviare (per substituting or abbreviating (for example, es. invece di dire babbo, scrivono papa' e they write "dad" instead of "daddy" and so così via). Questo perche' ci priva di arric- on). By doing this, we could enrich our vochire il nostro vocabolo o altre cose anche cabulary or it might be useful for those who come per chi avesse le protesi acustiche e wear hearing aids and can therefore "pick ha la possibilita' di "captare" le voci, con up" the voices, by turning the volume up volume della tv alzata, mentre legge i sotto- while reading the subtitles (this is a useful titoli (un utile allenamento per "sincroniz- training to "keep up" with the words scrollzare" le parole come facevo a mio tempo) ing, as I used to do in the past). Finding e trovando due parole diverse tra parlato e two different words could cause confusion scritto potrebbe dare confusione alla perso- in the hearing impaired viewer, and, as time na sorda e con il tempo non si ha piu' voglia passes by, the viewer could give up trying to di ascoltare proprio perche' non si e' piu' hear because what they can hear and read in sintonia di sentire e di leggere in parti is different.

uguali.

\begin{tabular}{|l|l|l}
\hline sarebbe utile includere come sottotitolazio- & It would be useful to always reproduce the
\end{tabular} ne sempre il testo integrale quindi anche $\mathrm{i}$ text verbatim, including dialectal forms, detti o le parlate in forma dialettica nonchè sayings and accents, as well as song lyri testi delle canzoni (ad es. in stile Karao- ics (e.g. in karaoke style). ALL THE BEST ke). AUGURI PER LA TESI WITH YOUR THESIS WRITING

Vorrei che nei sottotitoli venisse riprodotto I'd like verbatim subtitles, there's no need perfettamente il parlato, senza inutili abbre- for pointless abbreviations.

viazioni.

Che la sottotitolazione sia pura e integrale. I'd like subtitling to be pure and verbatim, Ciò rispecchia che la ricezione telesiva sia in order for the viewing experience to be uguale per i non sordi che per gli udenti. the same both for the hearing impaired and $[\ldots]$

for the hearing viewers. [...]

Esiste una falsa credenza per cui il sordo è There's a false myth that deaf people are per forza un mezzo analfabeta, ne consegue half-illiterate, and the result is that subtitles che spessissimo i sottotitoli sono: diversi are often different [from what you can hear estremamente semplificati estremamente on screen], extremely simplified, extremely sintetici cosa che spesso consenste la cor- synthesised. This allows for a full compreretta cmprensione del senso, ma ne fa per- hension of the overall sense, but prevents dere tutte le sfumature, cosa che impoveri- from catching the nuances. This negatively sce la narrazione impacts the storytelling

\section{More subtitling in cinemas}

i televisivi con i sottotitoli non si offrono TV programmes are seldom subtitled! And quasi mai! Oppure quando vado a cinema when I go to the cinema with my friends, con amici soffro perchè manca i sottotitoli I'm sad because subtitled screenings are not available

Per i sottotitoli vorrei che almeno un cine- Regarding subtitles, I'd like that at least one ma a Milano trasmettesse solo film sototti- cinema in Milan screened subtitled films tolati in italiano sia in lingua originale che both in Italian and in a foreign language... in italiano...per fare ciò è importante spin- To this purpose, it would be important that gere udenti e sordi ad andare a quel cinema. hearing and deaf viewers alike went to that In bocca al lupo per la tesi! cinema. All the best with your thesis writing! 

da sempre desidero vedere anche in italia in
tutte le citta i sottotitoli al cinema.so che è
una questione di mentalità, ma mi auguro
che la tecnologia ci aiuti!! complimenti x
il test, molto interessante.spero sia uitle a
tutti. buon lavoro.

Secondo me sarebbe ideale sottotitolare anche i cinema ... Magari fare delle sale apposite $\mathrm{x}$ i sordi di modo che anche loro possano andare al cinema, tranquillamente come tutti gli altri ...

magari migliorassero la qualità dei sottotitoli, e soprattutto integrarli nei Cinema.

Nelle multisale cinematografiche non esistono sale attrezzate per i non udenti come nella maggior parte in Europa.

Gradirei i sottotitoli anche al cinema. Nelle maggior parte della città italiane mancano totalmente!!!

Da grande appassionato di cinema, quello che manca in Italia è la possibilità di vedere film in sala sottotitolati per non udenti.... sarebbe giusto consentire la possibilità di fruire del cinema anche ai non udenti.
I've always desired to go to an Italian cine$\mathrm{ma}$, in whatever city, and see subtitled films. I know that it has to do with our mind-set, but I really hope that technology could lend a hand!! Congratulations on your survey, it was very interesting. Hopefully it will be useful to all of us. Keep up the good work.

I think subtitled screenings at cinemas would be just the ideal solution... They could reserve a cinema screen for the hearing impaired moviegoers so that they too could go to the cinema just as the rest of the world does...

I wish that the quality of subtitles would improve and, above all, that they would offer subtitled screenings at cinemas.

[Italian] Movie theatres are not equipped so as to offer subtitled screenings, as happens in the rest of Europe.

I'd like to have subtitles also at the cinema. They are not available in the majority of Italian cinemas!!!

As I am a big movie fan, I recognise that what is missing in Italy is the possibility to go to subtitled screenings for the hearing impaired... it would be only fair to allow deaf people to enjoy cinema screenings.

\section{Avoid common technical problems}

i sottotitoli non devono assolutamente interrompere!!!!!!! moltisisme volte succede e si perde il filo, fa venire proprio tantissima rabbia non poter seguire tutto tutto per filo e per segno, non è possibile con la tecnologia del terzo millennio....grazie.!!!!!

PARLO PER RAI.qualche giorni i sottotitoli funziona bene. resto male colpa operatore o altro per esempio quando c e pubblicita $\mathrm{i}$ sottotitoli fermo blocca o indietro o niente. mi sono inervosito. penso operatore va bar o bagno.cosi i film cominciato dopo pubblicita operatore ancora pausa. sopratutto i sottotiloli non funziona bene quando ce pubblicita. In piu spesso film che ho visto c era sottotitoli.in poi film stesso titolo non ce sottotitoli.e un tecnologia obsoleto [...]
Subtitles should never suddenly disappear!!!!!! On innumerable occasions, it happens and you lose the thread of the conversation, this makes me really angry because it prevents me from following exactly [what's going on on screen], this is not acceptable with all that the third-millenium technology can grant.... Thanks!!!!

I'M TALKING ABOUT RAI. On some days everything works just fine. In the rest of the cases, it all gets messed up, it's the operators fault, or for example, during commercial breaks subtitles disappear or stop working. I get angry and I think that maybe the operator has gone to the bar or to the toilet. After the commercial break, subtitles still do not appear. This happens mainly when there are commercial breaks. Plus, subtitles were available on films in the past, the same films that now come without subtitles. It's an obsolete technology [...] 
Purtroppo i sottotitoli in tv in italia fanno Unfortunately, TV subtitling in Italy sucks, schifo, perchè non funzionano bene e spe- because they do not work smoothly. I was ravo che miglioravano ogni anno e invece hoping they would get better year after no mi sbaglio. all'estero credo che hanno year, but I was wrong. They have done giant fatto un passo gigante rispetto all'italia. steps abroad when compared to Italy.

Table 3 - Selection of survey participants' answers to Question 20

\section{Discussion}

In the present study, respondents to the questionnaire were asked a series of questions aimed at identifying their needs, preferences, expectations and requests. Personal and subtitle-related information as well as suggestions and comments were elicited to this purpose.

The results obtained from the present questionnaire-based research provide an initial framework within which to study the composition of the Italian users of SDH. In particular, they inform us about the main personal and physical characteristics of the participants and about respondents' preferences and suggestions regarding SDH.

Judging from the answers received from the surveyed group, the majority of respondents are adult, male viewers, who attended special schools for deaf children. Whether people have been educated in special schools for deaf children may make a difference in terms of the first language spoken. In fact, children who attend these special schools are usually, even though not necessarily, taught LIS (the Italian Sign Language) as their first language. This has consequences in terms of decoding strategies used when reading written texts, such as the subtitles that appear on screen. It is indeed believed that deaf people who use sign language as their first language use different decoding strategies with respect to those used by their hearing peers (De Linde \& Kay 1999). Because of these considerations, it is likely that these people use sign language as a means of decoding written texts (e.g. subtitles) (De Linde \& Kay 1999).

Most of the respondents suffer from profound hearing impairment and are deaf from birth, but because of their constant use of hearing aids, they are able to communicate using both sign language and oral language.

Furthermore, the majority of respondents do not suffer from eyesight problems nor from reading deficiencies, such as dyslexia. In spite of these last results, though, the questionnaire data also account for a significant percentage of respondents who are short-sighted, astigmatic or who suffer from reading deficiencies. Therefore, extra attention should be paid when deciding which fonts to choose for SDH so as to ensure maximum legibility. In order 
to avoid any errors in the reception of subtitles, fonts with characters whose shapes are non-interchangeable and non-symmetrical should be privileged. In particular, as Clark (2006b) suggests, fonts that present the following features (such as, Arial, Helvetica or Univers) should be avoided:

- Confusable character shapes, including all the classic combinations (Ill|, S568, rn m, cl d);

- Reversible character shapes (bdqpg), which generate confusion for dyslexics and others with reading-related learning disabilities.

- Too tight default spacing, particularly for captions, which glow, hence blur into each other.

- Geometric character shapes (OGQ are near-perfect circles by design), which translate poorly into low-resolution media like TV.

Digital television will also allow for better designed and more legible fonts to be used, as opposed to the traditional AlphaMosaic font used until now in analogue television.

Finally, most of the respondents are affiliated with ENS, an association that tends to prefer an approach in favour of sign language, as opposed to the policy of another important Italian association of Deaf people, the FIADDA, which tends to support the oralist approach, and subtitling in particular.

As regards subtitle-related issues, the majority of respondents said they use SDH on digital television.

Furthermore, most of survey respondents usually watch TV for 1-2 hours a day, choosing films and TV series over live programmes, with a clear preference for RAI TV channels.

These results are closely related to the answers given to Question 19 about the criteria used to assess the quality of the subtitled programme. According to survey respondents, SDH quality mainly depends on the quantity of subtitles provided, the legibility of subtitles on screen and the speed of subtitles. When addressing this topic, it should be pointed out that Italy still lacks legislation compelling all public and private TV broadcasters, as well as DVD distributors and cinemas, to provide minimum quantities of SDH per day (Remael 2007). However, RAI has committed itself to subtitle for the deaf and hard-of-hearing at least $70 \%$ of all programmes that are broadcast by its three public TV channels (RAI Uno, RAI Due, RAI Tre) by 2012 (RAI 2011: 6). This commitment results from a triennial agreement between the Italian Ministry of Communications and RAI. Hence, it can be understandable why most respondents chose RAI over other broadcasters in Question 18. 
The speed of subtitles, as the third most important criterion chosen by the surveyed group to judge the quality of $\mathrm{SDH}$, is another issue that has to be taken into consideration when creating or adapting subtitles for hearing impaired audiences.

In the final section of the questionnaire, respondents were prompted to express their suggestions and comments on any areas that they thought need improvement.

The most significant observation that has to be made at this point regards the claim for $100 \%, 24$ hours a day, 7 days a week subtitling on all analogue and digital, private and public TV channels. On this topic, there seems to be confusion among survey respondents: in fact, one of the main complaints resulting from Question 20 is that SDH is almost completely unavailable on digital TV channels, while the results of Question 13 indicate that the majority of respondents use SDH on digital TV channels.

Another issue regards the level of text adaptation in SDH. This much debated and controversial topic seems to lie at the heart of a lot of respondents, who expressed the wish that Italian subtitles be less adapted than they currently are. As Durante (2005: 11) explains,

Il grado di complessità dei sottotitoli della RAI cambia secondo il tipo di trasmissione, in considerazione del presunto livello di scolarizzazione e di competenza linguistica in italiano dell'utenza. Le trasmissioni destinate ai bambini presentano il più alto grado di semplificazione e di sintesi, seguite dai telefilm pomeridiani e dalle soap-opera. Anche queste trasmissioni sono abbastanza semplificate perché si presume siano seguite da un pubblico di un livello medio-basso di scolarizzazione o da persone anziane, con problemi uditivi. I film e ancor più i documentari sono invece i generi di trasmissioni dai sottotitoli meno facilitati. La sottotitolazione dei telegiornali è invece [...] integrale, mantenendo un linguaggio del tutto giornalistico. ${ }^{3}$

On the whole, the analysis of the results of the present questionnaire offers an indicative picture of the composition and preferences of a sample group of Italian users of SDH.

3. The degree of complexity of the subtitles provided by RAI changes according to the type of programme that is being broadcast. The presumed level of audience alphabetisation and linguistic competence in the Italian language are taken into consideration to the purpose of subtitling. Programmes for children are the most simplified and synthesised, followed by afternoon TV series and soap-operas. These programmes are also simplified too as it is supposed that they are watched by an audience with a medium to low level of alphabetisation, or by older people who suffer from hearing impairment. On the other hand, films and documentaries are the least facilitated programmes. TV news subtitling is, instead, mostly verbatim and the language used is rather journalistic. [My translation] 
Knowing what the needs of the intended recipients are is essential for the creation of high-quality, accessible subtitles. While the first section of the questionnaire was designed so as to give an overview of the personal and physical characteristics that shape the needs of deaf and hard-of-hearing people, the second one was conceived so as to judge the current level of satisfaction regarding SDH services as they are currently provided on the Italian media (TV, DVDs and cinemas). Finally, the free text space for suggestions and comments in the last section of the survey put the real recipients of SDH centre stage, letting them take the floor and speak for what they really need and want.

Finally, the information resulting from the analysis of the data herein presented may have interesting implications for professional translators and subtitlers when creating or adapting subtitles for the hearing impaired. For instance, the collected data might be relevant to determine patterns for: adaptation, condensation, synchronisation, rendition and conveyance of verbal and non-verbal information (speaker identification, sound effects, music and silences) and presentation of the text on screen in a legible form.

Obviously, these findings are based on a very limited sample of the Italian population that makes constant use of SDH. The results here exposed cannot be taken as statistical facts, but they can be used as a guide by all those people, primarily professional translators and subtitlers, who need to have a more precise idea of who their recipients are.

The main limitation of this study lies in the fact that, as is often claimed, deaf as opposed to hard-of-hearing people consider themselves in a different way: born-deaf people usually feel a greater sense of belonging to a separate community, that is ruled by precise conventions and by a well-defined language - sign language - which is often their first language. On the other hand, people who become deaf later in their lives tend to "identify themselves with the hearing community. They have acquired the condition through age or disease but they mainly partake of the social order of the community in which they were raised" (Neves 2009: 155). The present questionnaire was posted on various places on the Web, attended by people belonging mainly to the first category, who thus recognise their role inside the "deaf community" and actively participate in it. In this regard, Ivarsson (1992: 140) states that people who are born deaf make up "a small but significant proportion of the population (less than one-thousandth)." It is therefore possible that the "much larger group [that] suffers from acquired deafness or hearing impairment" (Ivarsson 1992: 140) might not be well-represented in this research, as they would not be likely to take this survey, either because they think of 
themselves as belonging to the hearing community or because they do not usually visit these websites. This may be the case of large groups of people who become deaf very late in their lives, or who gradually developed some kind of hearing impairment.

Future research in the field of audience design might take up from this initial and limited study and expand its scope thanks to more in-depth investigation, for example, into the influence that personal and physical characteristics (like the age of onset of deafness or the preferred way of communication) exert on the practice of subtitling.

\section{Conclusions}

In summary, the study that has been conducted here was aimed at defining an initial framework of the needs, expectations, preferences and requests of the actual users of SDH in Italy, in the belief that audience design should be one of the many preconditions that professional translators and subtitlers ought to be aware of before starting the actual work of subtitling.

By knowing the needs, expectations, preferences and requests of deaf and hard-of-hearing viewers, translators and subtitlers can be better prepared to cope with the issues of adaptation, condensation, synchronisation with sound and images, rendition of verbal and non-verbal information legibility issues.

In addition, profiling Italian deaf and hard-of-hearing users of SDH might also prove to be useful to those in charge of deciding which subtitling policies to adopt, as is the case of TV broadcasters and cinema managers: the questionnaire respondents made it clear by expressing their suggestions and comments that there is still a long way to go before they can call themselves happy with the services they get. In the end, it is not all about quality, but quantity as well: digital TV broadcasters and cinemas will have to make this accessible revolution happen.

\section{References}

ADAMS, John. W. \& Pamela Rohring. (2004) Handbook to service the deaf and hard of hearing: a bridge to accessibility. San Diego: Academic Press.

CHAUme, Frederic. (2004) Cine y traducción. Madrid: Cátedra.

Clark, Joe. (2006a) Debunking the research on Tiresias Screenfont. Full text-version at: http://screenfont.ca/fonts/today/Tiresias/debunk. [Retrieved in June 2011, from Media Access].

Clark, Joe. (2006b) Response to CMP Captioning Key. Full text-version at: $<$ http://joeclark.org/access/captioning/CMP/>. [Retrieved in June 2011, from Media Access]. 
Clark, Joe. (2007a) Don't show printouts to grannies and call that a test. Full textversion at: http://joeclark.org/appearances/atypi/2007/caption-subtitle. [Retrieved in June 2011, from Media Access].

Clark, Joe. (2007b) Reading the tube. Full text-version at: http://joeclark.org/design/print/readingthetube.html. [Retrieved in June 2011, from Media Access].

DE Linde, Zoe, \& Neil Kay. (1999) The Semiotics of Subtitling. Manchester: St Jerome Publishing.

Di Silvio, Milena. (2006) Le necessità dei sordi: aspetti tecnici. Full text-version at: http://www.intralinea.it/specials/respeaking/ita_more.php?id=482_0_41_ 0_M. [Retrieved in June 2011, from inTRAlinea: Speciale Respeaking].

DíAz Cintas, Jorge \& Aline Remael. (2007) Audiovisual Translation: Subtitling. Manchester: St Jerome Publishing.

Durante, Maria Maddalena. (2005) La televisione e la sordità. Un'analisi della sottotitolazione per non udenti nelle emittenti televisive italiane. Institut Supérieur de Traducteurs et Interprètes: Bruxelles. Full text-version at: http://voice.jrc. it/educ/univ/thesis/durante/durante_it.pdf. [Retrieved in June 2011].

ENS. (2002) "Il gradimento dei programmi sottotitolati proposti alla pagina $777 \mathrm{di}$ Televideo 1.” In Scripta Volant: la RAI per i sordi. Torino: RAI Eri. pp. 169-182.

IVARSSON, Jan. (1992) Subtitling for the media: A handbook of an art. Stockholm: Transedit.

JENSEMA, Carl J. (1998) "Viewer reaction to different television captioning speeds." American Annals of the Deaf, vol.143. pp. 318-324.

LISO, Lisa; Paola Picone \& Silvia Rampelli. (2002) "Proposta di un manuale di sottotitolazione per i sordi”. In: VV.AA (eds.) 2002. Scripta Volant: La RAI per i sordi. Torino: RAI Eri. pp. 183-234.

NEVES, Josélia. (2005) Subtitling for the Deaf and Hard-of-Hearing (PhD Thesis, tutored by Dr Jorge Díaz Cintas). Full text-version at: http://roehampton.openrepository.com/roehampton/bitstream/10142/12580/1/neves\%20audiovisual. pdf. [Retrieved in June 2011].

NeVES, Josélia. (2009) "Interlingual Subtitling for the Deaf and Hard-of-Hearing." In: Díaz Cintas, Jorge \& Gunilla Anderman (eds.) 2009. Audiovisual Translation: Language Transfer on Screen. Basingstoke: Palgrave Macmillan. pp. 151-185.

OFCOM (2005) Subtitling - An issue of speed? Full text-version at: http://stakeholders.ofcom.org.uk/binaries/research/tv-research/subt.pdf. [Retrieved in June 2011, from Ofcom - Independent regulator and competition authority for the UK communication industries].

Pirelli, G. (2005) La sottotitolazione nei cinema: le esigenze degli spettatori audiolesi nei cinema. Full text-version at: http://voice.jrc.it/media/cinema/cinema_needs_it.htm. [Retrieved in June 2011, from Voice Project]. 
RAI (2011) Capitolato Tecnico per la fornitura del servizio di sottotitolazione di programmi televisivi pre-registrati $e$ in diretta per non udenti, per Televideo (Disciplinare di Gara Allegato 3). Full text-version at: http://www.fornitori.rai.it/ bandi/Sottotitolazione_di_programmi_televisivi_preregist.html\#. [Retrieved in June 2011].

REMAEL, Aline. (2007) "Sampling subtitling for the deaf and hard-of-hearing in Europe." In: Díaz Cintas, Jorge; Pilar Orero \& Aline Remael (eds.) 2007. Media for all: Subtitling for the Deaf, Audio Description and Sign Language. Amsterdam - New York: Rodopi. pp. 23-52.

Schilperoord, Joost; Vannia De Groot \& Nic Van Son. (2005). Non-verbatim captioning in Dutch Television Programs: A Text Linguistic Approach. Full textversion at: http://jdsde.oxfordjournals.org/content/10/4/402.full.pdf+html. [Retrieved in June 2011, from Oxford University Press Journals].

Sokoli, Stavroula. (2009). "Subtitling norms in Greece and Spain." In: Díaz Cintas, Jorge \& Gunilla Anderman (eds.) Audiovisual Translation: Language Transfer on Screen. Basingstoke: Palgave Macmillan. pp. 36-48.

TERCEDOR SÁNCHEZ, María Isabel; Laia Burgos; Dolores Herrador Molina; Irene Márquez Linares \& Lourdes Márquez Alhambra (2007). "Parámetros de análisis en la subtitulación accessible." In: Jiménez Hurtado, Catalina (ed.) 2007. Traducción y accessibilidad: Subtitulación para sordos y audiodescripción para ciegos. Frankfurt am Main: Peter Lang. pp. 41-51.

\section{BIONOTE / NOTA BIOGRÁFICA}

\section{Agnese Morettini}

Agnese Morettini holds a degree in Language Mediation and a Master's Degree in Modern Languages for International Communication and Cooperation, both from the University of Macerata. Her research interests include audiovisual translation and media accessibility, specifically interlingual subtitling, Subtitling for the Deaf and Hard-of-hearing (SDH) and, as of lately, respeaking and Audio Description (AD). At the moment, she is a freelance translator and proofreader, mainly in the audiovisual field (subtitling and voice-over for DVDs and broadcasting). She also works on script adaptation, spotting, timing and SDH projects for international film festivals (Venice Film Festival, Rome Film Festival and Turin Film Festival). As of June 2011, she is participating in a European-level project, aimed at investigating the reception of translated audio descriptions and audio introductions (from English into Italian) by a group of Italian visually impaired people. 
Agnese Morettini es licenciada en Mediación Lingüística y licenciada superior en Lenguas Modernas para la Comunicación y Cooperación Internacional por la Universidad de Macerata. Sus temas de investigación abarcan distintos aspectos de la traducción y accessibilidad audiovisual: la subtitulación interlingüística, la subtitulación para sordos y, recientemente, el rehablado y la audio descripción. Actualmente trabaja como traductora y revisora autónoma en el campo de la traducción audiovisual (subtitulación y voice-over para DVD y canales de televisión). Se ocupa también de adaptación de guiones, spotting, timing y subtitulación para sordos en ocasión de festivales de cine internacionales (Festival Internacional de Cine de Venecia, Festival de Cine de Roma, Turín Film Festival). A partir de junio de 2011, participa en un proyecto a nivel europeo que tiene como objetivo investigar la recepción de audio descripciones y audio introducciones, traducidas del inglés al italiano, por parte de un grupo de discapacitados visuales italianos. 